\title{
Assessment of the Secondary Metabolite Patulin and Lycium Barbarum Fruit on INS-1 Rat Pancreatic B-Cells
}

\author{
Madeha N.Al-Seeni ${ }^{1}$ \\ Ahmed M.Ali ${ }^{2}$ \\ Nagwa M. Elsawi ${ }^{3}$ \\ Asma S.Abdo ${ }^{4}$
}

'Biochemistry Department, Faculty of Science, King Abdel-Aziz University, Jaddah, Saudi Arabia.

${ }^{2}$ Chemistry department, faculty of science, Al-Azhar University, Assiut Branch, Egypt

${ }^{s, \lambda}$ Chemistry Department, Faculty of Science, Sohag University, Sohag, Egypt

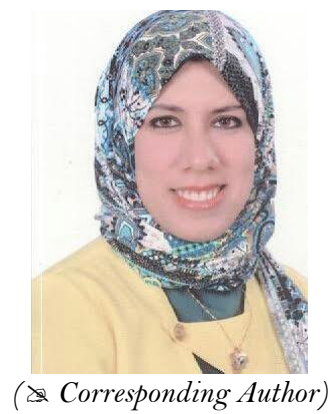

\begin{abstract}
Patulin has been shown to have diabetogenic effects in mice. The effects on pancreatic $\beta$-cell viability and function of secondary metabolite patulin were investigated. Using forty adult albino male rats which divided into 4 groups. Control group was injected subcutaneously daily with distilled water for one week; group I was injected subcutaneously daily with Patulin (0.2 $\mathrm{mg} / \mathrm{kg} /$ day) for two weeks. Group II was injected with the same toxin and dose for two weeks after that they were treated by Goji extract ( $2 \mathrm{ml} / \mathrm{kg} /$ day.) for two weeks. Group III was treated by Goji for two weeks after that they were injected with patulin for two weeks. Some biochemical parameters of blood samples for experimental rodents were evaluated. Patulin group shows significant increase in amylase and glucose levels. But level of C-peptide and Insulin decreased significantly in this group. However, there is no significant alteration in Lipase level between patulin group and control. Groups treated with goji extract in groups two and three (therapeutic and prophylactic) illustrated non significant alteration in biochemical parameters compared to control.
\end{abstract}

Keywords: Patulin, Pancreas, Goji extract, Insulin.

Citation | Madeha N.Al-Seeni; Ahmed M.Ali; Nagwa M. Elsawi; Citation Madeha N.Al-Seeni; Ahmed M.Ali; Nagwa M. Elsawi; Patulin and Lycium Barbarum Fruit on INS-1 Rat Pancreatic BCells. Agriculture and Food Sciences Research, 4(1): 24-29. History:

Received: 4 April 2017

Revised: 3 July 2017

Accepted: 6 July 2017

Published: 11 October 2017

Licensed: This work is licensed under a Creative Commons Attribution 3.0 License $($ co)

Publisher:Asian Online Journal Publishing Group
Contribution/Acknowledgement: All authors contributed to the conception and design of the study.

Funding: This study received no specific financial support

Competing Interests: The authors declare that they have no conflict of interests.

Transparency: The authors confirm that the manuscript is an honest, accurate, and transparent account of the study was reported; that no vital features of the study have been omitted; and that any discrepancies from the study as planned have been explained.

Ethical: This study follows all ethical practices during writing.

\section{Contents}

1. Introduction

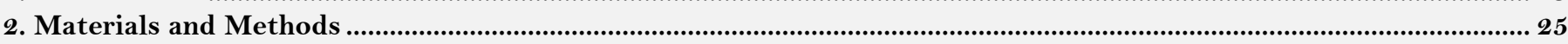

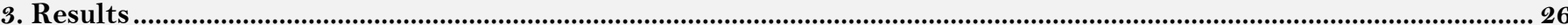

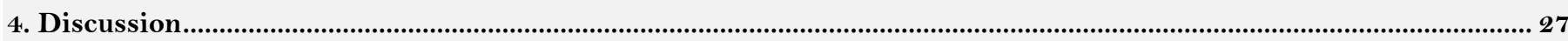

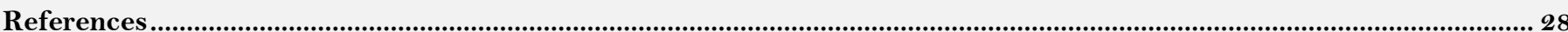




\section{Introduction}

Mycotoxins are reported to be important for infection and possibly growth under natural environmental conditions. A known example of mycotoxins is patulin [1]. Patulin has been used as a model for exposure to secondary metabolites via contaminated food; it is produced by fungi, in particular Penicillium and Aspergillus, which may contaminate food products like apples and apple juice. The effects of patulin have been studied extensively, where it has been shown to be both genotoxic and neurotoxic through its covalent binding to essential sulphydryl groups in proteins and peptides. This toxicity of patulin has already been demonstrated against various mammalian cells and has been attributed to its ability to inhibit RNA and protein synthesis. It is also interfere with the activity of many enzymes such as glycogen phosphorylase, glucose- 6-phosphatase, hexokinase and aldolase that are considered crucial for cell survival [2].

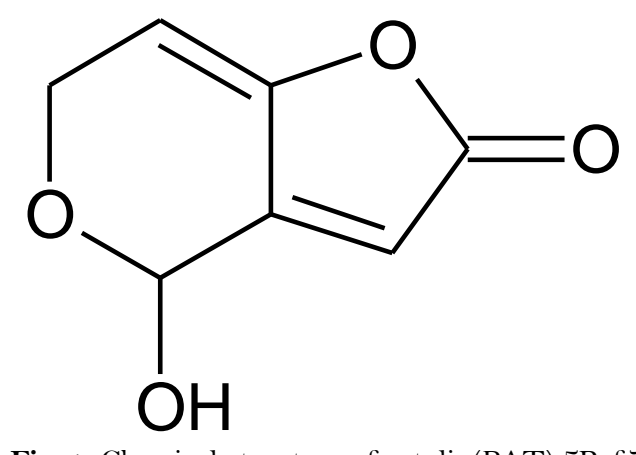

Fig-1. Chemical structure of patulin(PAT) [Ref $]$

Lycium barbarum fruit, generally called goji berry or wolfberry, is a well-known traditional Chinese medicine. Goji berry has shown a wide range of health benefits such as the functions and activities associated with the liver, kidney, eyesight, sex, immune system, and longevity [3]. Also, it improves the insulin resistance of the cells and prevents damage from diabetes [4]. In addition, Lycium barbarum may help in lowering glucose level in diabetic person. In vitro hypoglycaemic effect assay indicated that LBP may decrease high glucose level by protecting pancreatic $\beta$-cells from oxidative damages and alleviating the insulin resistance in liver cells. Hypoglycaemic activity of Lycium barbarum fruit may be correlative with polysaccharides, a mainly functional composition, considered as potential candidate for developing a new beneficial food or new anti-diabetic agent [5]. It has long been used to treat diabetes mellitus and related hyperlipidemia [6].

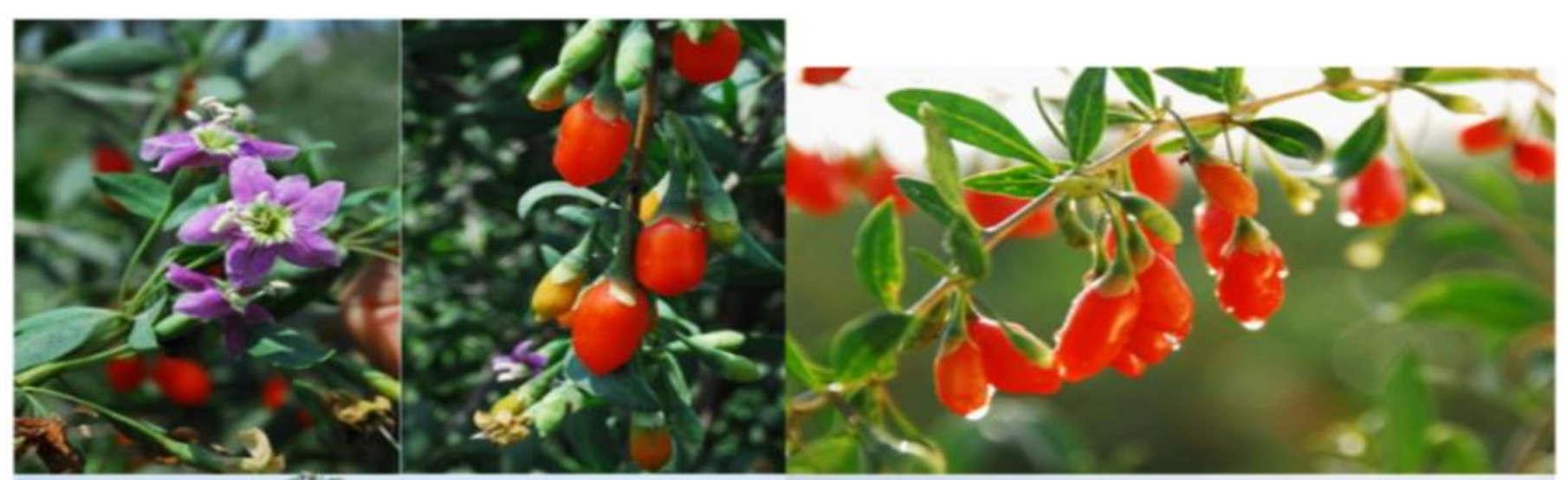

Fig-2. LyciumBarbarum (goji berry) [7]

In this study, the biochemical profile of fungal secondary metabolite, patulin, on the INS- 1 rat $\beta$-cell was examined, in order to evaluate the possible role of Goji extract in reversing patulin toxicity.

\section{Materials and Methods}

\subsection{Chemicals}

Patulin (4-hydroxy-4H-furo[3, 2-c $]$ pyran-2 (6H)- one) was obtained from Sigma Chemical Company.

\subsection{Extraction of Goji Wine}

Goji berry was extracted according to method described by Yang and Baojun [8]where, $5 \mathrm{~g}$ of goji fruits, 25 $\mathrm{mL}$ alcohol and $75 \mathrm{ml}$ distilled water were put into Erlenmeyer flask (the ratio of goji berry and alcohol is referred to the ratio of making commercial goji wine). The Erlenmeyer flask was sealed with parafilm and tinfoil and put in refrigerator for 5 days. filtration was made to separate the solid and liquid phases after finishing steeping process, solvent is removed from filtrate by rotatory evaporator to obtain crude goji extract.

\subsection{Animals and Experimental Design}

\subsubsection{Animals}

Forty male adult albino rats weighing 240-300 $\mathrm{g}$ at the age of 3.0-4.0 months were obtained from the animal house, Faculty of Medicine, Assiut University. They were housed in standard environmental conditions $\left(22 \pm 3^{\circ} \mathrm{C}\right.$, and a $12 \mathrm{~h} \mathrm{light/} \mathrm{dark} \mathrm{cycle} \mathrm{as} \mathrm{perCPCSEA} \mathrm{guidelines)} \mathrm{and} \mathrm{fed} \mathrm{with} \mathrm{standard} \mathrm{rodent} \mathrm{diet.}$

The rats were randomly assigned to four groups of 10 rats each ( 5 rats in each cage) and treated as follows:

Control group: injected subcutaneously daily with distilled water;

Group I: injected subcutaneously daily with Patulin $(0.2 \mathrm{mg} / \mathrm{kg} /$ day $)$ for two weeks respectively. 
Group II: injected by Patulin as a previous dose for two weeks after that they were treated with goji extract (2 $\mathrm{ml} / \mathrm{kg} /$ day) for another two weeks.

Group III: treated by goji extract for two weeks then, they were injected subcutaneously with the same dose of the toxin also for another two weeks.

\subsection{Biochemical Studies}

Animals were anesthetized under light diethyl ether and blood samples were collected from the heart into plain tubes and stored at $-20^{\circ} \mathrm{C}$ until analyses were performed. Sera were used for the measurement of Amylase, Lipase, Glucose, C-peptide and Insulin. Level of Amylase was measured according to Ranson [9] level of Lipase was measured according to Rick [10] level of Glucose was measured according to Trinder [11] level of C-peptide was measured by ELISA kit that was purchased from IMMUNOSPEC Company and level of Insulin was measured by ELISA kit that was purchased from Demeditec.

\subsection{Statistical Analysis}

The data were presented as mean \pm SEM and the level of significance between groups were $*$ p $<0.05, * *$ $\mathrm{p}<0.01$, *** $\mathrm{p}<0.0001$. They were analysed using one-way ANOVA followed by Newman-keuls test. statistical graph pad prism 5 was used for the analysis of the data.

\section{Results}

The biochemical changes were studied in blood of male albino rats as a result of administration of a dose from Patulin (0.2 mg/kg b. w.) and observed over a period of two weeks (GI) compared to the control group. GII treated by Patulin as previous dose for two weeks after that they were injected subcutaneously with goji extract $2 \mathrm{ml} / \mathrm{kg}$ /day for two weeks. In addition GIII treated by goji for two weeks then, they were injected subcutaneously with the same toxin for two weeks.

Table. 1. and Fig. 3. represent the mean value of Amylase concentration ( $\mu$ kat/l) of G I treated animals for two weeks to be $(40.46 \pm 0.4)$ which was highly significantly increased from normal value of control group (33.75 \pm 0.32 ), where $\mathrm{p}<0.001$. On the other hand, Non-significant changes in the mean value of amylase concentrations were observed between GII $(32.18 \pm 0.4)$ and GIII $(30.76 \pm 0.8)$ compared to control.The mean value of Lipase concentration ( $\mu \mathrm{kat} / \mathrm{l})$ table.1.and Fig.4. of G1 (0.185 \pm 0.007), G II and G III showed no significant change $(\mathrm{P}>0.05)$ compared with control group. Table.1. and Fig.5.represent the mean value of glucose concentration $(\mathrm{mmol} / \mathrm{l})$ of $\mathrm{G}$ I was significantly elevated to $(10.82 \pm 1.33)(\mathrm{p}<0.05)$ than normal control samples $(7.604 \pm 0.383)$. This level was still slightly elevated to $8.31 \pm 0.77$ in GII ( $>0.05)$, and $9.77 \pm 0.64$ in GIII $(p<0.05)$, but it is still within normal range with control group. The mean value of C-peptide concentration $(\mathrm{ng} / \mathrm{ml})$ in Table.1. and Fig.6.showed significant decrease $(\mathrm{P}<0.05)$ compared with control. However, No significant changes in the mean value of C-peptide were observed between GII and GIII compared to control. The mean value of Insulin concentration $(\mu \mathrm{lU} / \mathrm{ml})$ in Table.1and Fig.7. showed significant decrease $(\mathrm{P}<0.05)$ compared with control. However, This decrease returned again back to normal value in GII and GIII respectively with non-significant change compared to control group.

Table-1. Effect of Patulin (0.2 mg/Kg b. w.) and Goji extract ( $2 \mathrm{ml} / \mathrm{kg} /$ day) on Some Biochemical Parameters of Male Rats:

\begin{tabular}{l|l|l|l|l}
\hline Groups & Control & GI & GII & GIII \\
\hline Amylase $(\mu \mathrm{kat} / \mathrm{l})$ & $33.75 \pm 0.32$ & $40.46 \pm 0.4^{* * *}$ & $32.18 \pm 0.4 \mathrm{~N} . \mathrm{S}$ & $30.76 \pm 0.8 \mathrm{~N} . \mathrm{S}$ \\
\hline Lipase $(\mu \mathrm{kat} / \mathrm{l})$ & $0.217 \pm 0.04$ & $0.189 \pm 0.03 \mathrm{~N} . \mathrm{S}$ & $0.207 \pm 0.01 \mathrm{~N} . \mathrm{S}$ & $0.241 \pm 0.007 \mathrm{~N} . \mathrm{S}$ \\
\hline Glucose $(\mathrm{mmol} / \mathrm{l})$ & $7.604 \pm 0.383$ & $10.82 \pm 1.33^{*}$ & $8.31 \pm 0.77 \mathrm{~N} . \mathrm{S}$ & $9.77 \pm 0.64 \mathrm{~N} . \mathrm{S}$ \\
\hline C-peptide $(\mathrm{ng} / \mathrm{ml})$ & $0.341 \pm 0.02$ & $0.197 \pm 0.01^{*}$ & $0.297 \pm 0.01 \mathrm{~N} . \mathrm{S}$ & $0.338 \pm 0.03 \mathrm{~N} . \mathrm{S}$ \\
\hline Insulin $(\mu \mathrm{l} \mathrm{U} / \mathrm{m})$ & $0.58 \pm 0.101$ & $0.383 \pm 0.13^{*}$ & $1.35 \pm 0.10^{* * *}$ & $1.54 \pm 0.13^{* * *}$ \\
\hline
\end{tabular}

Note: Values are expressed as the mean \pm SE for 10 animals in each group.

GI $=$ Treated group with Patulin.

GII , GIII = Treated groups with Goji

Significant change in comparison between groups

*p $<0.05 ; * * * \mathrm{p}<0.001$

N.S Non significant $(\mathrm{P}>0.05)$

\section{amylase}

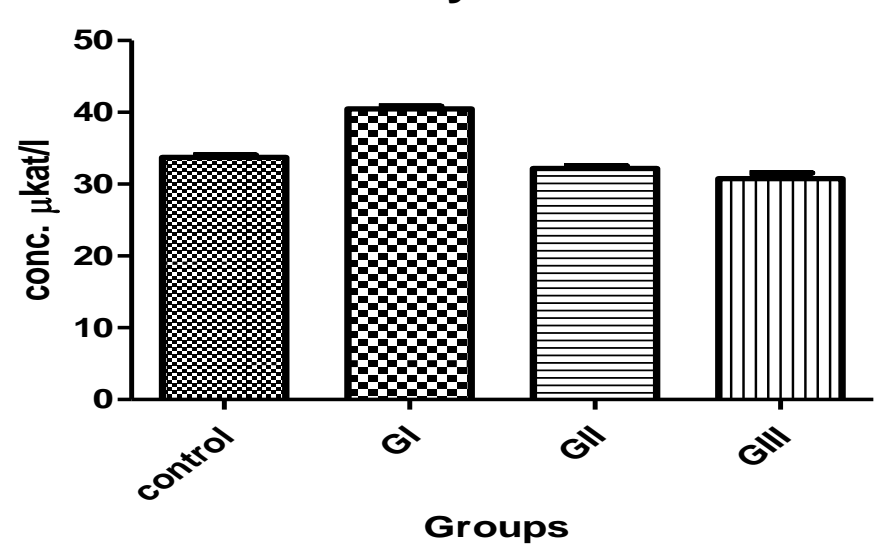

Fig-3. $\alpha$-amylase levels in control and treated groups with patulin (2 $\mathrm{mg} / \mathrm{kg} . \mathrm{B} . \mathrm{W})$ and goji extract (2 ml/kg.B.W) 


\section{lipase}

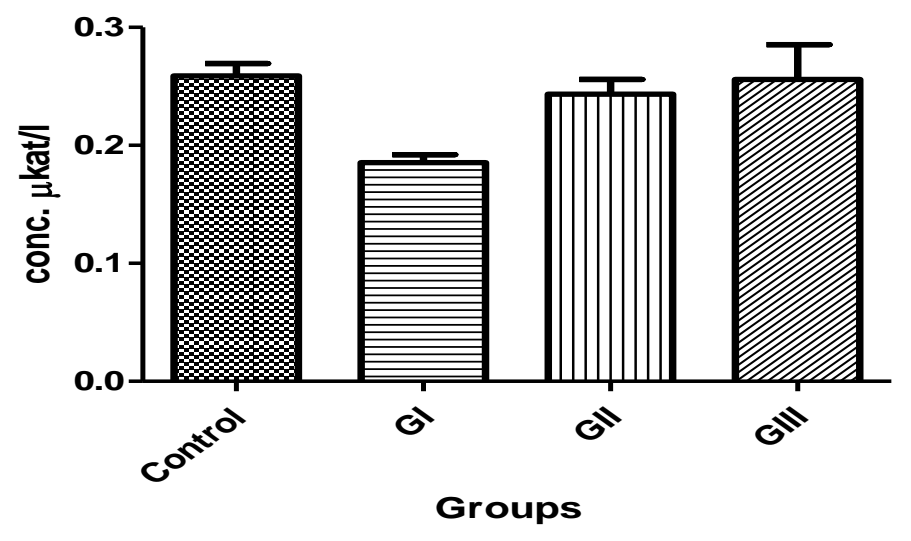

Fig-4. Lipase levels in control and treated groups with patulin $(2$ $\mathrm{mg} / \mathrm{kg} . \mathrm{B} . \mathrm{W})$ and goji extract $(2 \mathrm{ml} / \mathrm{kg} . \mathrm{B} . \mathrm{W})$

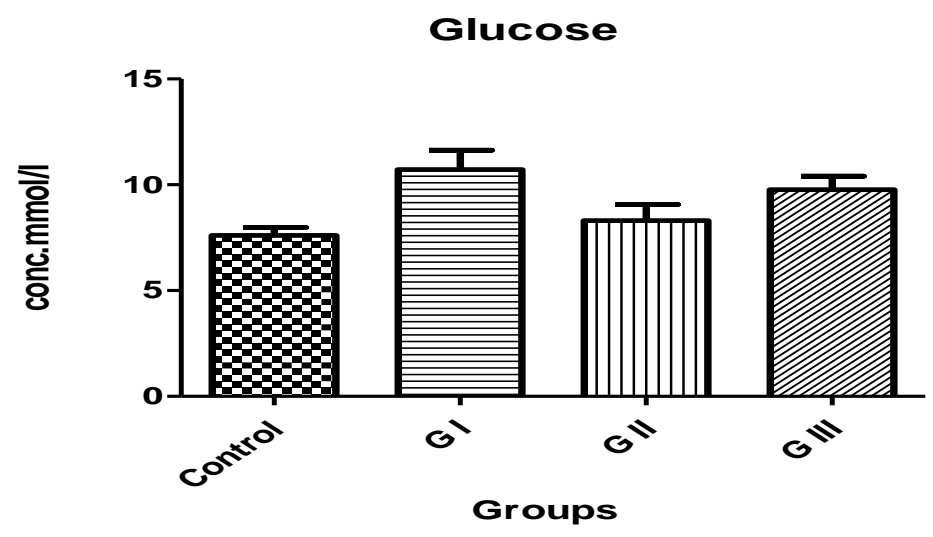

Fig-5. Glucose levels in control and treated groups with patulin (2 $\mathrm{mg} / \mathrm{kg} . \mathrm{B} . \mathrm{W})$ and goji extract $(2 \mathrm{ml} / \mathrm{kg} . \mathrm{B} . \mathrm{W})$

\section{C-peptide}

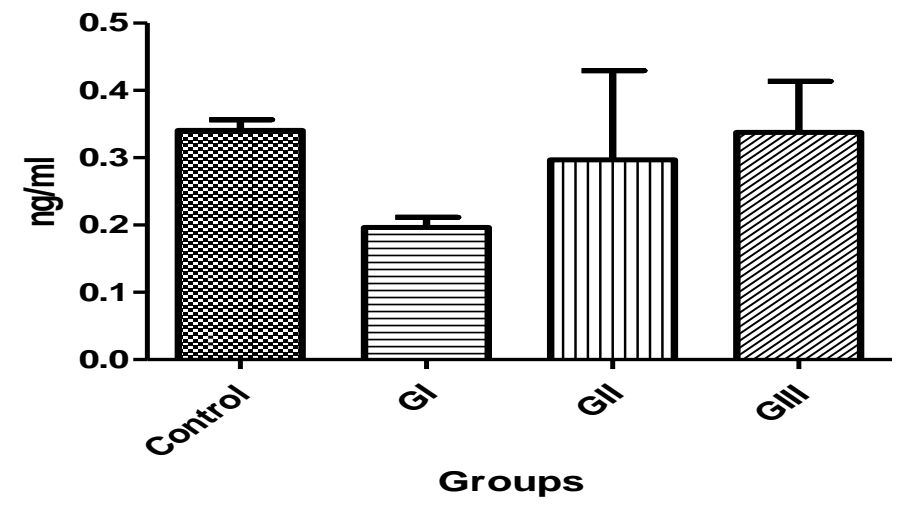

Fig-6. C-peptide levels in control and treated groups with patulin (2 $\mathrm{mg} / \mathrm{kg} . \mathrm{B} . \mathrm{W})$ and goji extract (2 ml/kg.B.W)

Insulin

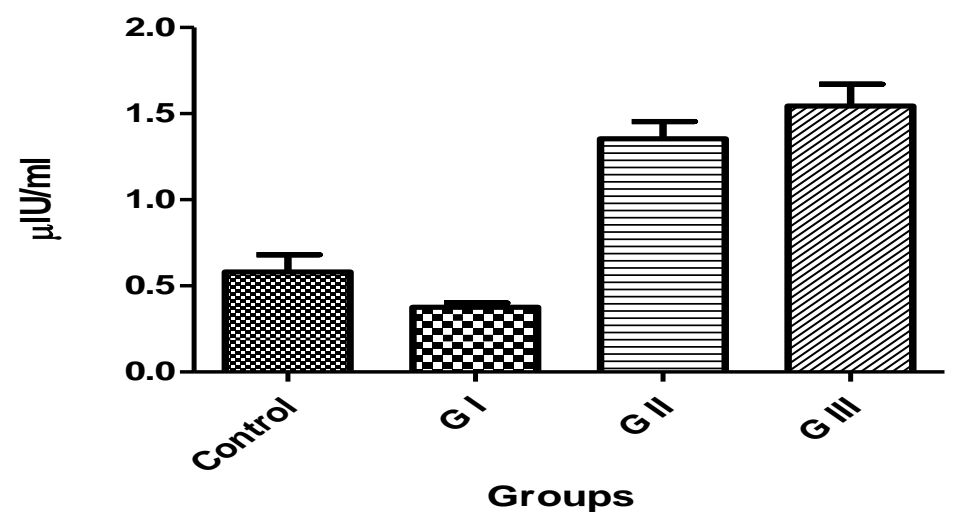

Fig-7. Insulin levels in control and treated groups with patulin (2 $\mathrm{mg} / \mathrm{kg} . \mathrm{B} . \mathrm{W})$ and goji extract $(2 \mathrm{ml} / \mathrm{kg} . \mathrm{B} . \mathrm{W})$

\section{Discussion}

The present study is a biochemical analysis on the effect of microbial product, patulin on INS-1 pancreatic beta cells $(\beta$-cells) and the possible role of goji extract as a therapy on pancreas dysfunction. The destruction of $\beta$ - cells and development of type 1 diabetes have been linked with exposure to environmental factors [12] which may contribute up to $50 \%$ of the risk of developing this type of diabetes [13]. The most important environmental factors are thought to be infection (viral infection), diet (lack of particular food during childhood) and some inorganic compounds (arsenate ions) $[14,15]$. To study pancreatic function of rats treated with patulin, $\alpha$-amylase, 
lipase, glucose, c-peptide and insulin have been measured as biochemical indicators. Alpha-amylase catalyzes the

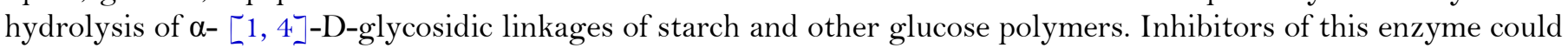
be of use in the treatment of diabetes, resulting in inhibition of starch breaking and decreases levels of blood glucose $[16]$. Because of the harmful side-effects of synthetic products and the fact that plants are easily accessible, interest in drugs of herbal origin has significantly increased. Our present biochemical data in the patulintreated rats showed an obvious increasing $(\mathrm{p}<0.001)$ in pancreatic levels of amylase as it is shown in Table. 1 and Fig.3. These elevation levels attributed to acute pancreatitis caused by patulin [17]. Also, many reports have dealt with the relationship between blood amylase and carbohydrate metabolism [18-20]or hormones that affect carbohydrate metabolism [20-22]. These studies showed that high levels of amylase result from administration of hormones that decreases utilization of carbohydrate or in physiological states of diminished carbohydrate utilization.

Another parameter is lipase, which is triacylglycerol acylhydrolase and an omnipresent enzyme with physiological significance and industrial potential. It catalyzes the hydrolysis of triglycerides to glycerol and free fatty acids. It is soluble in water and hydrolyzes insoluble substrates to more polar lipolytic products. Lipase is released from pancreatic acinar cells and reabsorbed by the kidney tubules So, it remains elevated for prolonged period which may be helpful in late presenting cases [23]. In this study, there is non-significant $(\mathrm{P}>0.05)$ change between patulin treated group and control as it is shown from Table. 1. and Fig.4. Where, Many studies have reported a negative predictive value of serum lipase in diagnosing acute pancreatitis to be between $94-100 \%$ even if amylase increases significantly [24, 25].

The digestive tract breaks down carbohydrates such as, starch and sugars found in many foods to glucose, a form of sugar that enters the bloodstream. With the help of the hormone insulin, cells found in the body absorb glucose and use it for energy. When the body doesn't make enough insulin (pancreas dysfunction) leading to accumulation of sugar in the blood and diabetes. In our study level of glucose in the blood was measured after administration of patulin for two weeks $(\mathrm{G} \mathrm{I})$ and it shows highly significant increase $(\mathrm{P}<0.05)$ in the mean value in Table 1 and Fig 5. This leads to damaging nerves and blood vessels and thus complications such as heart disease, stroke, kidney disease, blindness, dental disease, and amputations. Other complications of diabetes may increase susceptibility to other diseases and loss of mobility with aging [26].

In addition, c-peptide and insulin levels in serum were measured. C-peptide is produced in equal amounts to insulin and can therefore be used to assess endogenous insulin secretion in type-1-diabetes. The physiology of Cpeptide makes it appropriate for assessing insulin secretion. Insulin is produced in the pancreatic b-cells by enzymatic cleavage of the prohormone precursor proinsulin to produce insulin and C-peptide in equimolar amounts. Its half-life is longer than insulin $(20-30$ vs. $3-5 \mathrm{~min})$ and it therefore circulates at concentrations approximately five times higher in the systemic circulation [27, 28]. From Table.1 and Fig.6 it is cleared that mean value of c-peptide in rats treated with patulin shows significant decrease $(\mathrm{P}<0.05)$ compared with control. This scarce value confirms previous results obtained from amylase and glucose that is patulin induced type 1 diabetes in male rats after subcutaneous injection for 2 weeks. Because dropped levels of c-peptide means significant destruction of $\beta$-cells and only $10 \%$ of normal cell mass remains [29].

Insulin is known to facilitate the absorption of glucose through the specialized membrane of the insulin sensitive cells which invariably results in an increase in blood glucose level due to delayed glucose uptake [30]. Data from Table.1 and Fig.7. show that there is significant decrease in the mean value $(\mathrm{P}<0.05)$ compared with control. Insulin and glucagon have distinct actions in diabetes where, they show that the impairment of pancreatic exocrine functions is due to insulin deficiency and relative glucagon predominance [31]. This reducing of insulin caused by patulin in G I affect on pancreatic function resulting in changes in the composition and quality of pancreatic juice as well as its decreased production leading to accumulation of glucose in the blood and this agreed with the increasing in serum glucose showed in Fig.5. [32].

From table 1 we observe that levels of amylase, glucose and c-peptide return to normal values of control in group II and group III (treatment with goji extract after and before patulin respectively) and also, observe that insulin levels show highly significant increase compared to control. The most effective methods for treatment of diabetes are inhibition of digestion and absorption of carbohydrates in small intestine. That is happening in two manners, The first is inhibition digestion of carbohydrates with inhibition of alpha amylase and the second is inhibition of absorption via sodium/glucose co-transporters [16, 33]. Goji berries contain many nutrients with high biological activity, such as polysaccharides, carotenoids, phenylpropanoids and others. The polysaccharide complex is the most important and the most abundant group of compounds present in goji fruits where it comprises 5-8\% of dried matter of the fruits. Luo, et al. [34] have investigated the relation between supplementation with different polysaccharide fractions of goji fruit and the levels of glucose in blood. lowered blood glucose levels were recognized as substantial hypoglycemic effects. It was found that all goji preparations resulted in significantly decreased blood glucose levels after 10 days of treatment in the tested animals, indicating that there was hypoglycemic effect. implying that L. barbarumpolysaccharides were major bioactive components in the hypoglycemiceffect. Also, antioxidative protective mechanisms illustrated by Li [35] who said that after goji polysaccharide fractions treatment, The antioxidative activity of superoxide dismutase, catalase and glutathione was significantly increased. Moreover, free radical scavenging activity was also elevated.

In conclusion, this study illustrates that patulin is cytotoxic to INS-1 cells, leading to the possibility of this compound may contribute to the development of diabetes, the assumption being that this secondary product can be transported to the pancreas via the blood from the source of its production. And this study confirmed hypoglycemic effect of LBP found in goji berries.

\section{References}

[1] A. V. Christian, v. S. Bianca, G. Attila, K. Helmut, L. Reinhard, S. Wilhelm, and S. Siegfried, "Enhanced mycotoxin production of a lipase-deficient fusarium graminearum mutant correlates to toxin-related gene expression," European Journal of Plant Pathology, vol. 117, pp. 1-12, 2007. View at Google Scholar 
B. N. Raid, A. R. Mark, C. Abdesslam, M. A. John, and L. G. Martyn, "Effects of the microbial secondary metabolites pyrrolnitrin, phenazine and patulin on INS-1 rat pancreatic B-cells," FEMS Immunol Med Microbiol, vol. 63, pp. 217-227, 2011. View at Google Scholar | View at Publisher

W. M. Tang, E. Chan, C. Y. Kwok, Y. K. Lee, J. H. Wu, C. W. Wan, R. Y. Chan, P. H. Yu, and S. W. Chan, "A review of the anticancer and immunomodulatory effects of lycium barbarum fruit," Inflammopharmacology, vol. 20, pp. 307-314, 2012. View at Google Scholar

C. Jiang, Z. Zhi-Wei, S. Hui-Ping, H. Lan-Jie, F. Xue-Wen, H. Zhi-Xu, S. Tao, Z. Xueji, J. Z. Ruan, G. Ling, C. Chuanhai, and Z. Shu-Feng, "An evidence-based update on the pharmacological activities and possible molecular targets of Lycium barbarum polysaccharides," Drug Design, Development and Therapy, vol. 9, pp. 33-78, 2015. View at Google Scholar | View at Publisher

[5] K. Bartosz and A. Gramza-Michałowska, "Goji Berry (Lycium barbarum): Composition and health effects - a review," Polish Journal of Food and Nutrition Sciences, vol. 66, pp. 67-75, 2016. View at Google Scholar

[6] Q. Y. Li, Healthy functions and medicinal prescriptions of lycium barbarum (Gou Ji Zi). Beijing: Jindun Press. pp: 1-16, 2001.

[7] A. Harunobu and R. F. Norman, "A review of botanical characteristics, phytochemistry, clinical relevance in efficacy and safety of lycium barbarum fruit (Goji)," Food Research International, vol. 44, pp. 1702-1717, 2011. View at Google Scholar |View at Publisher

[8] S. Yang and X. Baojun, "Diffusion profiles of health beneficial components from goji berry (Lyceum Barbarum) marinated in alcohol and their antioxidant capacities as affected by alcohol concentration and steeping time," Foods, vol. 2, pp. 32-42, 2013. View at Google Scholar | View at Publisher

[9] J. Ranson, "Curr Prob Surg 1979; 16:1. Salt WB II, Schnker S. Medicine 1976; 55:269. Stefanini P, Ermini M, J Am Surg 1965; 1 10:866 Henry RJ, Chiamori N. Clin Chem 19610; 6:434. Kaufman RA, Tietz NW," Clinical Chemistry, vol. 26 , p. 486, 1980.

[10] W. Rick, "Zeittschrift clinical chemistry," Clinical Biochemistry, vol. 7, pp. 530 - 536, 1969.

[11] P. Trinder, "Determination of glucose in blood using glucose oxidase with an alternative oxygen receptor," Annals of Clinical Biochemistry, vol. 6, pp. 24-27, 1969. View at Publisher

[12] K. A. Hans, V. Outi, H. Heikki, I. Jorma, and K. Mikael, "Environmental factors in the etiology of type 1 diabetes," American Journal of Medical Genetics, vol. 115, pp. 18-29, 2002. View at Google Scholar

[13] M. A. Myers, K. D. Hettiarachchi, J. Ludeman, A. Wilson, C. Wilson, and P. Zimmet, "Dietary microbial toxins and type 1 diabetes," Annals of the New York Academy of Sciences, vol. 1005, pp. 418-422, 2003. View at Google Scholar

[14] H. W. Peng, "Environmental factors in the development of type 1 diabetes," Reviews in Endocrine E Metabolic Disorders, vol. 7, pp. 149-162, 2006.

[15] M. J. Richer and M. S. Horwitz, "Coxsackievirus infection as an environmental factor in the etiology of type 1 diabetes," Autoimmunity Reviews, vol. 8, pp. 611-615, 2009. View at Google Scholar | View at Publisher

[16] M. Najafian, M. Z. Jahromi, and M. J. Nowroznejhad, "Phloridzin reduces blood glucose levels and improves lipids metabolism in streptozotocin-induced diabetic rats," Molecular Biology Reports, vol. 1, pp. 1-8, 2011.

[17] K. J. Carroll, B. Herrick, T. Gipson, and P. L. Suzanne, "Acute pancreatitis: Diagnosis, prognosis, and treatment," American Family Physician, vol. 75, pp. 1513-1520, 2007. View at Google Scholar

[18] D. A. Dreiling, H. D. Janowitz, D. Marshall, and P. Haemmerli, "Relationship between blood amylase and factors affecting carbohydrate metabolism. I. The regulation of blood amylase levels in subjects without pancreatic disease," American Journal of Digestive Diseases, vol. 3, pp. 214-2 19, 1958. View at Google Scholar | View at Publisher

[19] D. A. Dreiling and E. L. Bierman, "Correlation between plasma amylase activity and concentration of plasma non-esterifled fatty acids (NEFA)," Proceedings of the Society for Experimental Biology and Medicine, vol. 95, pp. 496-497, 1957. View at Google Scholar | View at Publisher

[20] D. A. Dreiling, W. K. Rosenthal, M. Kass, and H. D. Janowitz, "Relationship between blood amylase and factors affecting carbohydrate metabolism," American Journal of Digestive Diseases, vol. 4, pp. 731- 736, 1959. View at Google Scholar | View at Publisher

[21] H. A. Cope and M. Blatt, "The activity of the blood serum amylase in the hypophysectomized dog," American Journal of Physiology, vol. 182 , pp. $428-434,1938$.

[22] R. E. Pfeffer and J. W. Hinton, "Some relationships between adrenal medullary and cortical substances and exocrine secretion of the pancreas," Gastroenterology, vol. 31, pp. 746 - 750, 1957. View at Google Scholar

[23] T. Cartier, P. Sogni, F. Perruche, O. Meyniard, Y. E. Claessens, J. F. Dhainaut, and G. Der Sahakian, "Normal lipase serum level in acute pancreatitis: A case report," Emergency Medicine Journal, vol. 23, pp. 701-702, 2006. View at Google Scholar | View at Publisher

[24] A. Z. Al-Bahrani and B. J. Ammori, "Clinical laboratory assessment of acute pancreatitis," Clinica Chimica Acta, vol. 362, pp. 26-48, 2005. View at Google Scholar | View at Publisher

[25] B. Sternby, J. F. O'Brien, A. R. Zinsmeister, and E. P. DiMagno, "What is the best biochemical test to diagnose acute pancreatitis? A prospective clinical study," Mayo Clinic Proceedings, vol. 71, pp. 1138-1144, 1996. View at Google Scholar | View at Publisher

[26] A. Shuldiner, "National institutes of diabetes and digestive and kidney diseases, NIH Publication No. 14-5164," 2014.

[27] K. S. Polonsky, J. Licinio-Paixao, B. Given, W. Pugh, P. Rue, and J. Galloway, "Use of biosynthetic human C-peptide in the measurement of insulin secretion rates in normal volunteers and type I diabetic patients," Journal of Clinical Investigation, vol. 77, pp. 98-105, 1986. View at Google Scholar | View at Publisher

[28] J. Licinio-Paixao, K. S. Polonsky, B. D. Given, W. Pugh, D. Ostrega, and B. F. Frank, "Ingestion of a mixed meal does not affect the metabolic clearance rate of biosynthetic human C-peptide," Journal of Clinical Endocrinology and Metabolism, vol. 63, pp. 401403, 1986. View at Google Scholar | View at Publisher

[29] S. Madsbad, T. Krarup, L. Regeur, O. K. Faber, and C. Binder, "Insulin secretory reserve in insulin dependent patients at time of diagnosis and the first 180 days of insulin treatment," Acta Endocrinol (Copenh), vol. 95, pp. 359-363, 1980. View at Google Scholar

[30] J. Cardenas, E. Alvarez, A. M. S. deCastro, J. M. Sanchez, M. Valmaseda, S. W. Elson, and J. V. Sinisterra, "Screening and catalytic activity in organic synthesis of novel fungal and yeast lipases," Journal of Molecular Catalysis B: Enzymatic, vol. 14, pp. 111-123, 2001. View at Google Scholar | View at Publisher

[31] H. P. Harding, H. Zeng, Y. Zhang, R. Jungries, P. Chung, H. Plesken, D. D. Sabatini, and R. D., "Diabetes mellitus and exocrine pancreatic dysfunction in perk- /- mice reveals a role for translational control in secretory cell survival," Molecular Cell, vol. 7, pp. 1153-1 163, 2001. View at Google Scholar | View at Publisher

[32] K. H. Kim, H. S. Lee, C. D. Kim, H. J. Chun, C. W. Song, S. H. Um, H. S. Ryu, and J. H. Hyun, "Evaluation of pancreatic exocrine function using pure pancreatic juice in noninsulin-dependent diabetes mellitus," Journal of Clinical Gastroenterology, vol. 31, pp. 5154, 2000. View at Google Scholar | View at Publisher

[33] M. Najafian, A. Ebrahim-Habibi, and P. Yaghmaei, "Core structure of flavonoids precursor as an antihyperglycemic and antihyperlipidemic agent: An in vivo study in rats," Acta Biochimica Polonica, vol. 57, pp. 553-560, 2010. View at Google Scholar

[34] Q. Luo, Y. Cai, J. Yan, M. Sun, and H. Corke, "Hypoglycemic and hypolipidemic effects and antioxidant activity of fruit extracts from Lycium barbarum," Life Sciences, vol. 76, pp. 137-149, 2004. View at Google Scholar | View at Publisher

[35] X. M. Li, "Protective effect of lycium barbarum polysaccharides on streptozotocin-induced oxidative stress in rats," International Journal of Biological Macromolecules, vol. 40, pp. 461-465, 2007. View at Google Scholar | View at Publisher 